\title{
Methods of Analysis of Environmental Diversity of Plants
}

\author{
Yuliya A Dorogova ${ }^{1 *}$, Lyudmila A Zhukova ${ }^{2}$, Nina V Turmuhametova ${ }^{2}$, Tatiana A Polyanskaya ${ }^{3}$, Alexander A Notov ${ }^{4}$ and Svetlana M Dementyeva ${ }^{4}$ \\ ${ }^{1}$ The Faculty of Physical Culture, Sports and Tourism, Mari State University, Lenin Square 1, Yoshkar-Ola 424000, Russian Federation \\ ${ }^{2}$ The Institute of Medicine and Natural Sciences, Mari State University, Lenin Square 1, Yoshkar-Ola 424000, Russian Federation \\ ${ }^{3}$ Research Department, Federal State Organization, National Park Mari Chodra, Central Street 73, Krasnogorsk 425090, Mari El Republic, Russian Federation \\ ${ }^{4}$ The Faculty of Biology, Tver State University, Zhelyabova 33, Tver 170100, Russian Federation
}

*Corresponding author: Dorogova YA, The Faculty of Physical Culture, Sports and Tourism, Mari State University, Lenin Square 1, Yoshkar-Ola 424000, Russian

Federation; E-mail: julya_dorogova@rambler.ru

Received: May 23, 2016; Accepted: August 25, 2016; Published: September 01, 2016

Copyright: @ 2016 Zhukova et al. This is an open-access article distributed under the terms of the Creative Commons Attribution License, which permits unrestricted use, distribution, and reproduction in any medium, provided the original author and source are credited.

\section{Abstract}

There are considered new approaches to the analysis of an ecological variety of plants with use of ecological scales. There are offered the quantitative methods of determination of ecological valency and tolerance of species of plants. There are estimated ecological positions of forest and meadow plants in different parts of areas in the Mari EI Republic, the Moscow, Tver regions of Russia. The carried-out analysis of conditions of cenopopulations' habitats (central processing unit) of plants of various vital forms showed that all of them borrow in different parts of areas of the territory with rather narrow ranges of the considered abiotic factors. It testifies to their fitness to cumulative influence of a certain set of climatic and soil factors of different regions. Determination of potential ecological valency and the characteristic of species on scales of factors gives the chance to solve a problem of a quantitative assessment of ecological tolerance of $t$ species of various vital forms and strategy in relation to separate factors. The indicators of the potential and realized ecological valency and an index of tolerance offered by us can widely be applied to the characteristic of ecosystems in which cenopopulation of plants, for an assessment of ecological positions of types are presented. Use of this approach is also actually in comparative floristics and in the ecological analysis of the protected plants.
\end{abstract}

Keywords: Cenopopulation of plants; Ecological diversity; Ecocenotic groups; Ecological indicator values (ecological scales); Ecological tolerance; Ecological valence; Red Book; Protected species of plants

\section{Introduction}

One of the central problems of population ecology is to develop the methods to assess an ecotope, revealing the effects of each individual and a combination of factors in the study population, and their members or intrapopulation groups, on biocenoses and ecosystem.

Ecological properties of plants are largely determined by their ability to colonize certain habitats. Modern understanding of ecosystems clearly emphasizes their abiotic components (ecotopes) and biotic (biocenoses) and take into account the impact of solar energy and man.

The purpose of this paper is to analyze the ecological diversity of plants, including a new version of the scales of D.N. Tsyganov [1] and new methods for determining the ecological valence and tolerance of a species of plant [2-4].

In today' s ecology the growing attention is attracted to the problem of determining the ecological status of species and biocenoses in relation to particular abiotic factors. As early as in the middle of the 19th century, a general perception was proposed about the individuality of species [5]. Almost at the same time, E. Warming [6] developed a qualitative classification of species according to their ability to use a particular share of gradient (for example, based on moisture: xerophytes, mesophytes, hygrophytes, hydrophites; on light: sciophytes and heliophytes) [5].

Later, allocating the plants with the same relationship to their environment, B.A. Keller [7] introduced the concept of "ecological groups." At the beginning of the 20th century, a number of foreign scientists suggested that abiotic environmental factors determine the specialization of species in plantcommunities [8-10].

However, only the work of L.G. Ramensky [11] showed the real possibility of using the ecological properties of plants for determining the expressivity of abiotic factors. L.G. Ramensky named the tables containing the reaction of individual species to various environmental factors-ecological scales. Ramensky with his coauthors [12] first published the five-gradient range scales in 1956. The term "ecological indicator values" was inroduced later, but it had been used in English with the same meaning Ramensky put in his "ecological scales." We will use the term "ecological indicator values" for Ramensky's and Tsyganor's "ecological scales".

In 1983, the ten-gradient scales of ecological indicator values by D.N. Tsyganov appeared. They were based, same as the scales of L.G. Ramensky, on geobotanical descriptions from different types of communities that included local populations (cenopopulations) of 2,129 plant species.

Later, this problem was developed in Europe by H. Ellenberg $[13,14]$ and E. Landolt [15]. They published ecological indicator values for Western Europe and Switzerland. These ecological indicator values represent the average realized niches of studied species. As new data emerge, more regional ecological indicator values appear in Russia covering usually only part of the ranges of the most common species but determining more precisely their ecological status in the region [16-19].

Further progress was linked to the development of computer programs that allow to obtain from geobotanical descriptions a set of environmental assessments of phytocoenosises (plant communities) and habitat of populations of studied species: for example, the programs "EcoScale' [20] and "EcoScaleWin" [21,22]. 
The next step in the end of 20th century was made by foreign and domestic scholars who began to use concepts of valence and ecological tolerance of species that describe the range of adaptation to one factor or to the combination of two or more factors [5,23-26].

T. Scott [23] allocated groups of "stenopatient and mesopatient," which further were divided into oligo-, meso-, and poli-subgroups. These groups and subgroups were emphasizing the position of the species in the beginning, middle, or end on the scale of factor. J. Kolasa and N. Waltho [24] distinguished species types into "generalists" and "specialists," considering the first as widely specialized and the second as highly specialized to specific factors.

Used by foreign and national scientists, the concept of ecological valence and tolerance are still mainly applied both to one factor and to a group of factors $[26,27]$. Now for the quantitative characteristic of the relation of a species to a certain factor, we suggested using only the concept of "ecological valency", and for a complex of factors"tolerance" or "biontnost" [2,4,28-30].

At the same time, the term "ecological valence" is proposed for the quantitative measure of each factor and the term "tolerance" for a complex of factors [29]. For classification of species in terms of ecological valence, the separation into steno-, hemisteno-, meso-, hemievri- and evrivalent factions is implemented for each factor.

\section{Materials and Methods}

We consider the potential ecological valence (PEV) as a measure of adaptation of population to only one environmental factor. Then potential ecological position can be evaluated as the range of values of the specific environmental factor within which the populations of this species are able to live. For grading scale of each factor we used, as in the previous scales, not its particular values but steps (or score) it is ranked into. Potential ecological valence is calculated as the ratio of the number of steps taken by a given species on the particular scale to the total number of steps on this scale. In other words, the value of PEV equals to the proportion of species interval of steps to the full scale [2]:

$$
\mathrm{PEV}=\left(\mathrm{A}_{\max }-\mathrm{A}_{\min }+1\right) / \mathrm{n}
$$

where $A_{\max }$ and $A_{\min }$ are maximum and minimum values of steps occupied by a given species on the scale; $n$ - total number of steps on the scale, 1 -added as the 1 st scale division with which the range of species begins.

By conducting studies of local populations or plant communities, we can measure the realized (or implemented) ecological valence (REV). Itcan be represented by the following formula [2]:

$$
\mathrm{REV}=\left(\mathrm{A}_{\max }-\mathrm{A}_{\min }+0.01\right) / \mathrm{n}
$$

where $\mathrm{A}_{\max }$ and $\mathrm{A}_{\min }$ are maximum and minimum values of steps on the scale occupied by particular populations; $n$ - total number of steps on the scale; 0.01 - added as the 1st scale division where studied local populations begin to appear.

The effectiveness of the development of ecological space by specific populations of species for each factor is evaluated using the index of ecological efficiency (Kec.eff.). It is represented by the following formula [2,3]:

$$
\text { Kec. eff. }=\mathrm{REV} / \mathrm{PEV} * 100 \%
$$

where PEV is potential ecological valence and REV is realized ecological valence.
Value REV/PEV reveals the degree of usage by studied local populations the ecological potential of species.

The distribution of species among factions of valence is based on expert evaluation.

According to it, species are considered the stenovalent if they occupy less than $1 / 3$ of scale, evrivalent-more than $2 / 3$ scale, and the other species - mesovalent [2]. The last group can be divided into hemisteno-, meso-, and hemievrivalent factions. Populations of stenovalent species are characterized by low potential ecological valence and can withstand only limited changes of certain environmental factors. Populations of evrivalent species - high PEV - can occupy different habitats within extremely wide gradients of this factor.

However, a simple list of PEV for each species and each factor is difficult to assimilate as information due to its cumbersome nature. We consider it expedient to use the concept of "steno-meso-evribiont" to describe the specific type of relationship to the cumulative effects of several factors. Therefore, each species has a set of REV whose number is the number of considered factors. It should be noted that REV of any species covers only a part of the scale of a single factor. The sum $(\Sigma)$ of REV amounts for several factors is usually greater than one and represents a Fragment of the Fundamental Ecological Niche (FFEN) of a particular species.

Adding together the REV values of one species can be considered as correct operation because the obtained sum is a part of the hyperspace of ecological niches of species whose boundaries are defined by the upper boundaries of the scales.

Correspondence of the sum of potential ecological valence for a given species with the number of scales, keeping in mind that the contribution of each scale is equal to 1 , gives us a quantitative measure for steno-evribiont or an index of tolerance of this species (It). It can be represented in this formula $[3,4]$ :

$$
\mathrm{It}=\Sigma \mathrm{PEV} / \Sigma \text { scales of considered factors }
$$

To calculate the Climatic Index of Tolerance (It clim), we combined the four scales for ecological indicator values of D.N. Tsyganov [1]: $\mathrm{Tm}$-termoclimate, $\mathrm{Kn}$-continental climate, $\mathrm{Om}$-ombroclimate arid-humid, $\mathrm{Cr}$ - cryoclimate. To calculate the Soil Tolerance Index (It soil), we combined the five scales: $\mathrm{Hd}$ - soil moisture, $\mathrm{Tr}$ - saliniy of soil, $\mathrm{Nt}$ — soil nitrogen, $\mathrm{Rc}$ - soil acidity, $\mathrm{fH}$ - soil moisture variability. The scale of light-shading (Lc) stays alone.

For distribution of the species among the tolerance groups, the same principle is applied as for the distribution of the species among factions of ecological valence. Thus, the following factions of valence and tolerance of species can be distinguished:

- stenovalent (SV) and stenobiont (SB) - indicator of valence or index of tolerance does not exceed 0.33 ;

- hemistenovalent (HSV) and hemistenobiont (HSB) - from 0.34 to 0.45 ;

- mesovalent (MV) and mesobiont (MB) - from 0.46 to 0.56;

- hemievrivalent (HEV) and hemievribiont (HEB) - from 0.57 to 0.66 ;

- evrivalent(EV)and evribiont(EB) - from 0.67 and above.

The bigger is the It value, the higher, theoretically, is the possibility of using by populations of particular species the ecologically various habitats. 
The objects of this study were 2,362 species, for which, on the scale by D.N. Tsyganov, there were calculated new indicators of potential ecological valence and climatic and soil tolerance index.

The eco-cenotic groups (ECG) in the forest areas of a temperate climate [31] including 411 species were studied in more detail [2]; they were also considered the representatives of boreal eco-cenotic group. For them the analysis of ecological features of cenopopulation (CPU) of species in different parts of their area was carried out. As a result there were studied the CPU of 11 species of the wood synusia [32]. In the national park Mari Chodra, there were studied the CPU of 1 low shrub - blueberries (Vacciniummyrtillus L.), and from the forest herbs golden rod ordinary (Solidagovirgaurea L.) and one-flower grandiflora (Monesesuniflora (L.) A. Gray). The objects of research were also the CPU of 15 species of herbaceous polycarpic of the floodplain meadows of Northern Dvina, Oka, and Small Kokshaga [33,34].

For environmental parameters habitats CPU model species of vascular plants floristic lists taken from the geobotanical descriptions phytocenoses examined, processed using "EcoScaleWin" a computer program [22]. In the analysis of the obtained data the following statistical methods were applied: dispersive analysis of KraskelaWallice and median test, Vilkokson-Mann-Whitney's criterion, method main component [35].

By the ecological analysis of the vascular plants included in Red Books of the Tverregion [36] and the MariElRepublic (RME) [37] with the help of D.N. Tsyganor's scales [4] for each species, the ecological valency on each factor and tolerance on climatic and soil factors, and also the general tolerance, are determined.

\section{Results and Discussion}

\section{Ecological Features of Representatives of Different Eco-cenoticgroups}

Calculations of indices of tolerance of species for 8 ECG of the mixed, coniferous, broad-leafed and the deciduous forests of the European part of Russia have revealed an interesting pattern [2]. All prevalent species largest It is evri-hemievri- or mezobiont with rare manifestations of stenovalency on individual factors. This suggests that the main cenosis creator and dominant as wood and grass-shrub layer can only be the CPU types that exhibit high tolerance to most of the environmental factors considered. They dont have stenovalent position or there are one or two factors as a rare exception. Meso- and hemievribiont constituting a majority of the considered ECG combined symptoms and evrivalentnosti, the combination of their environmental positions, and therefore the importance of environmental valences may be different.

The CPU role of these types is filling of free fragments in the phytocenoses and the ability to live peacefully with the CPU of the other types. It allows confirming that ecological tolerance is considerable advantage in the interspecific competition, promotes active expansion of the species range, and defines stability at anthropogenous and ecological stresses. On the other hand, many stenobiontny and hemistenobiontny types, which are adapted for existence in the narrow ranges on a number of ecological factors, as a rule, act as assektator, become rare and endangered species as the combination of necessary narrow ranges of many factors is met much less often and less steadily.

Analysis of the ecological features of species of the boreal group of the European part of Russia has allowed establishing the prevalence of stenovalent types of thermo-climatic scales, ombro-climatic, soil moistening, the salt regime of soil, and variability of moistening. The domination of mesovalent plants is revealed-on scales of the soils acidity. At the same time the domination of fractions of the evrivalent fractions of plants is noted - on the scales of continentality of climate, cryoclimatic, richness of soils nitrogen, and illumination-shading. Thus, the representatives of boreal $\mathrm{ECG}$-dominants of the forest phytocenoses - show high tolerance to the majority of the considered factors and, as a rule, are evribionts or hemievribionts or, at leastmezobiontam and stenovalentnye position they occur on one or two factors. The Mezobiont types, making the majority in the considered eco-cenotic group exhibit signs of steno-, hemisteno-, hemievrievrivalentnosti and with different combinations of environmental products; CPU of these species is filled free places in phytocenoses. Belonging to the various life forms, as well as systematic position of boreal species does not determine the degree of their environmental adaptations. Therefore, clarification of ecological positions for each scale allows you to set any kind of factors limiting its spread.

\section{The Ecological Diversity of Forest Trees}

For subzone of coniferous-deciduous forests on the example of two geographic areas was studied ecological diversity of 11 species of woody plants; radar charts were drawn using indicators of potential and realized environmental valences (Figure 1) [32].

In the studied phytocenoses of the Moscow Region and the Mari El Republic are revealed very similar numerical values REV studied the CPU Acerplatanoides (Figure 1).

Indices of tolerance of tree species on climatic factors and the spread of some woody plants in Russia and neighboring countries $[37,38]$ are shown in Table 1.

\section{Ecological Characteristics of Cenopopulations in Different Parts of the Area}

Analyzing distribution of the model species of wood sinuziya on plant zones in the territory of Russia, the following regularity is revealed: the climatic index of tolerance is higher, the ecological amplitudes of types in relation to the modes of heat, humidity of air, severity of winters are wider, and the bigger number of zones cover

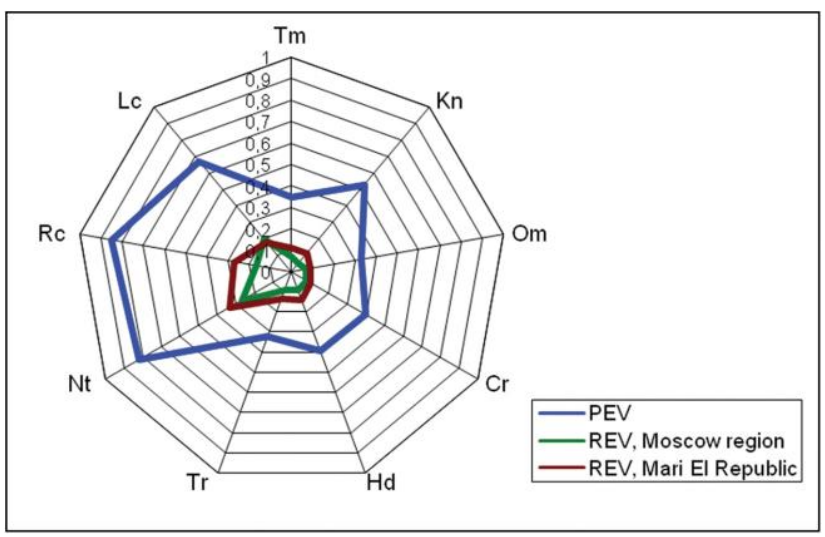

Figure 1: Potential (PEV) and realized (REV) studied ecological valence CPU Acer platanoides L. in the Moscow region and the Mari El Republic 
Citation: Dorogova YA, Zhukova LA, Turmuhametova NV, Polyanskaya TA, Notov AA, et al. (2016) Methods of Analysis of Environmental Diversity of Plants. Biol Med (Aligarh) 8: 354. doi: 10.4172/0974-8369.1000354.

Page 4 of 8

\begin{tabular}{|c|c|c|c|c|c|c|c|c|c|c|c|c|c|}
\hline \multirow[b]{3}{*}{ Species } & \multirow{2}{*}{\multicolumn{2}{|c|}{$\begin{array}{l}\text { Tolerance of } \\
\text { species }\end{array}$}} & \multicolumn{11}{|c|}{ Some plant zone with subzones } \\
\hline & & & \multirow{2}{*}{$\begin{array}{c}\text { Tundra } \\
\text { HST }\end{array}$} & \multicolumn{5}{|c|}{ Taiga } & \multicolumn{2}{|c|}{ Broadleaved } & \multicolumn{3}{|c|}{ Steppe } \\
\hline & Index CL & group & & FT & NT & MT & ST & MF & $\mathrm{BF}$ & $\mathbf{s}$ & NS & MS & ss \\
\hline Picea $\square$ fennica (Regel) Kom. & 0.23 & SB & & & + & + & + & + & & & & & \\
\hline Acer platanoides $\mathrm{L}$. & 0.40 & HSB & & & & + & + & + & + & + & + & & \\
\hline Euonymus verrucosa Scop. & 0.40 & HSB & & & & & + & + & + & + & + & & \\
\hline Quercus robur L. & 0.45 & MB & & & & & + & + & + & + & + & + & \\
\hline Tilia cordata Mill. & 0.47 & MB & & & & + & + & + & + & + & + & + & \\
\hline Frangula alnus Mill. & 0.55 & MB & & & + & + & + & + & + & + & + & + & + \\
\hline Sorbus aucuparia L. & 0.56 & HEB & + & + & + & + & + & + & + & + & + & & \\
\hline Betula pubescens Ehrh. & 0.8 & HEB & & + & + & + & + & + & + & + & + & & \\
\hline Betula pendula Roth & 0.60 & HEB & & & + & + & + & + & + & + & + & + & \\
\hline Pinus sylvestris $\mathrm{L}$. & 0.63 & HEB & + & + & + & + & + & + & + & + & + & & \\
\hline Populus tremula L. & 0.65 & HEB & & + & + & + & + & + & + & + & + & + & + \\
\hline
\end{tabular}

Remark: Index CL_index on the climatic factors; HST—hypoarctic southern tundra; FT—forest-tundra; NT—northern taiga; MT—middle taiga; ST—southern taiga; MF—subtaiga (mixed forest); BF—broadleaved forests; S—steppe; NS—northern steppes; MS—middle steppes; SS—southern steppes; SBstenobiont; HSB — hemistenobiont; MB—mesobiont; HEB-hemievribiont.

Table 1: Indices of tolerance of tree species on climatic factors and the spread of some woody plants in Russia and neighboring countries.

their areas [32]. It causes possibility of use of the considered indicators for the characteristic of an ecological variety. Ecological characteristics of cenopopulation of Vaccinium myrtillus on D.N. Tsyganor's scales are presented in Table 2.

Ecological positions of a boreal bush-blueberry - in different areas of researches are rather similar. The received ranges coincide on eight scales and differ on two: acidities of soils (Rc) and variability of moistening (fH). Ecological positions at V. myrtillus are shifted to the right - toward increase in action of a factor on Rc scale to 7.29 points (subacidic/neutral soils) and on $\mathrm{fH}$ scale - to 5.6 points (intermediate between weakly-varying and moderately variable moistening) [4,30]. Thus, it is possible to introduce amendments in ranges of this species in D.N. Tsyganor's scales. The greatest ecological opportunities at blueberry are realized on a scale of variability of moistening $-88 \%$.

\section{Ecological Features of Meadow Plants}

Inundated meadows - intrazonal type of vegetation, therefore the central processing units of types, forming such communities - have to have wide ecological ranges on climatic and soil factors that D.N. Tsyganor's scales confirm. Use of new methods of the analysis of an ecological variety of habitats of the central processing unit of the chosen model meadow types showed that on the majority of climatic factors they belong to evrivalent or hemievrivalent fractions.

\begin{tabular}{|c|c|c|c|c|c|c|c|c|c|c|c|}
\hline Ranges & ECOP & PEV & Murm & Arkh & NNov & Mosc & Chuv & Mari & Chel & SUM & $\begin{array}{l}\text { Kec. } \\
\text { eff. }\end{array}$ \\
\hline$\underset{(1-17)}{\mathrm{Tm}}$ & $2-9$ & 0.47 & $\begin{array}{c}4.67- \\
7.33^{*} 0.16^{* *}\end{array}$ & $\begin{array}{c}5.30-7.64 \\
0.14\end{array}$ & $\begin{array}{c}7.00-7.25 \\
0.02\end{array}$ & $\begin{array}{c}6.94-8.23 \\
0.08\end{array}$ & $\begin{array}{c}6.54-8.16 \\
0.10\end{array}$ & $\begin{array}{c}5.00-8.27 \\
0.19\end{array}$ & $\begin{array}{c}7.60- \\
7.900 .02\end{array}$ & $\begin{array}{c}4.67-8.27 \\
0.21\end{array}$ & 45 \\
\hline $\begin{array}{c}\mathrm{Kn} \\
(1-15)\end{array}$ & $3-15$ & 0.87 & $\begin{array}{c}7.20-9.00 \\
0.09\end{array}$ & $\begin{array}{c}7.98-9.31 \\
0.06\end{array}$ & $\begin{array}{c}8.25- \\
8.630 .03\end{array}$ & $\begin{array}{c}7.96-8.68 \\
0.05\end{array}$ & $\begin{array}{c}8.28-8.84 \\
0.04\end{array}$ & $\begin{array}{c}7.40-9.00 \\
0.11\end{array}$ & $\begin{array}{c}8.70-9.30 \\
0.04\end{array}$ & $\begin{array}{c}7.20-9.31 \\
0.14\end{array}$ & 16 \\
\hline $\begin{array}{c}\mathrm{Om} \\
(1-15)\end{array}$ & $7-12$ & 0.40 & $\begin{array}{c}7.67-9.00 \\
0.16\end{array}$ & $\begin{array}{c}8.12-9.23 \\
0.08\end{array}$ & $\begin{array}{c}8.40-8.63 \\
0.02\end{array}$ & $\begin{array}{c}8.05-8.82 \\
0.05\end{array}$ & $\begin{array}{c}8.40-9.10 \\
0.05\end{array}$ & $\begin{array}{c}7.67-9.78 \\
0.14\end{array}$ & $\begin{array}{c}8.10-8.30 \\
0.01\end{array}$ & $\begin{array}{c}7.67-9.75 \\
0.14\end{array}$ & 35 \\
\hline $\begin{array}{c}\mathrm{Cr} \\
(1-15)\end{array}$ & $2-10$ & 0.60 & $\begin{array}{c}5.67-7.33 \\
0.11\end{array}$ & $\begin{array}{c}5.92- \\
7.250 .09\end{array}$ & $\begin{array}{c}6.50-6.75 \\
0.02\end{array}$ & $\begin{array}{c}6.54-7.74 \\
0.08\end{array}$ & $\begin{array}{c}6.63-7.76 \\
0.09\end{array}$ & $\begin{array}{c}5.00-7.92 \\
0.20\end{array}$ & $\begin{array}{c}6.80- \\
7.800 .07\end{array}$ & $\begin{array}{c}5.00-7.92 \\
0.20\end{array}$ & 33 \\
\hline $\begin{array}{c}\mathrm{Hd} \\
(1-23)\end{array}$ & $10-19$ & 0.43 & $\begin{array}{c}12.25- \\
13.890 .07\end{array}$ & $\begin{array}{c}12.64- \\
14.830 .09\end{array}$ & $\begin{array}{c}13.05-13.88 \\
0.04\end{array}$ & $\begin{array}{c}11.95- \\
14.58 \\
0.12\end{array}$ & $\begin{array}{c}12.74- \\
14.670 .08\end{array}$ & $\begin{array}{c}11.33- \\
14.950 .16\end{array}$ & $\begin{array}{c}12.30- \\
12.800 .02\end{array}$ & $\begin{array}{c}11.33-14.95 \\
0.16\end{array}$ & 37 \\
\hline $\begin{array}{c}\operatorname{Tr} \\
(1-19)\end{array}$ & $1-7$ & 0.37 & $\begin{array}{c}3.80-5.25 \\
0.12\end{array}$ & $\begin{array}{c}3.88-6.85 \\
0.16\end{array}$ & $\begin{array}{c}4.62-5.32 \\
0.04\end{array}$ & $\begin{array}{c}4.22-6.22 \\
0.11\end{array}$ & $\begin{array}{c}4.39-5.96 \\
0.08\end{array}$ & $\begin{array}{c}4.00- \\
6.710 .14\end{array}$ & $\begin{array}{c}5.60-6.30 \\
0.04\end{array}$ & $\begin{array}{c}3.80-6.85 \\
0.16\end{array}$ & 44 \\
\hline $\begin{array}{c}\mathrm{Nt} \\
(1-11)\end{array}$ & $1-7$ & 0.64 & $\begin{array}{c}4.11-6.43 \\
0.21\end{array}$ & $\begin{array}{c}2.97-5.58 \\
0.24\end{array}$ & $\begin{array}{c}4.19-5.38 \\
0.11\end{array}$ & $\begin{array}{c}4.05-5.88 \\
0.17\end{array}$ & $\begin{array}{c}4.08-5.50 \\
0.13\end{array}$ & $\begin{array}{c}3.00-6.87 \\
0.35\end{array}$ & $\begin{array}{c}5.20-5.70 \\
0.05\end{array}$ & $\begin{array}{c}2.97-6.87 \\
0.36\end{array}$ & 56 \\
\hline $\begin{array}{c}\mathrm{Rc} \\
(1-13)\end{array}$ & $1-6$ & $0 ; 46$ & $\begin{array}{c}3.80-5.89 \\
0.16\end{array}$ & $\begin{array}{c}3.71-6.98 \\
0.25\end{array}$ & $\begin{array}{c}5.38-5.82 \\
0.04\end{array}$ & $\begin{array}{c}5.18-7.00 \\
0.11\end{array}$ & $\begin{array}{c}4.89-6.31 \\
0.11\end{array}$ & $\begin{array}{c}2.67-7.29 \\
0.36\end{array}$ & $\begin{array}{c}6.70-7.10 \\
0.03\end{array}$ & $\begin{array}{c}2.67-7.29 \\
0.36\end{array}$ & 77 \\
\hline $\begin{array}{c}\mathrm{fH} \\
(1-11)\end{array}$ & $1-4$ & 0.36 & $\begin{array}{c}2.71-5.00 \\
0.21\end{array}$ & $\begin{array}{c}2.27-5.53 \\
0.3\end{array}$ & $\begin{array}{c}3.33-4.85 \\
0.14\end{array}$ & - & $\begin{array}{c}3.35-4.87 \\
0.14\end{array}$ & $\begin{array}{c}2.46-5.78 \\
0.30\end{array}$ & $\begin{array}{c}5.30-5.60 \\
0.03\end{array}$ & $\begin{array}{c}2.27-5.78 \\
0.32\end{array}$ & 88 \\
\hline $\begin{array}{c}\text { Lc } \\
(1-9)\end{array}$ & $2-9$ & 0.89 & $\begin{array}{c}3.12-4.62 \\
0.16\end{array}$ & $\begin{array}{c}3.00-5.33 \\
0.26\end{array}$ & $\begin{array}{c}4.54-5.11 \\
0.06\end{array}$ & $\begin{array}{c}3.92-5.21 \\
0.16\end{array}$ & $\begin{array}{c}4.36-5.58 \\
0.14\end{array}$ & $\begin{array}{c}2.92-5.47 \\
0.28\end{array}$ & $\begin{array}{c}4.00-4.50 \\
0.06\end{array}$ & $\begin{array}{c}2.92-5.58 \\
0.30\end{array}$ & 33 \\
\hline
\end{tabular}

Remark. Ranges_Ranges of scales; ECOP_positions of species on the scales; PEV—potential ecological valence; Murm—Murmansk region; Arkh—Arkhangelsk region; NNov—Nizhny Novgorod Region; Mosc—Moscow region; Chuv—huvashia Republic; Mari—Mari El Republic; Chel—Chelyabinsk region; SUM—summarized indicators; Kec.eff.—coefficient of ecological efficiency, \%; *-a real range; **-implemented ecological valence

Table 2: Ecological characteristics of cenopopulation of Vaccinium myrtillus on D.N. Tsyganov's scales. 
Estimating potential valencies on climatic factors of 45 cenopopulation of 15 studied model species, it is possible to note that none of them can be carried to stenovalent and even hemistenovalent fraction. For the analysis of the relation of the CPU of model types to all combinations of climatic factors, the tolerance index (It klim) was calculated. It allows to define that the CPU of 12 considered species belong to the group of evribiont, the CPU of two species (Ranunculus repens L. and Veronica longifolia L.) - to hemievribionts and the CPU of single species (Ranunculus acris L.) - to mesobionts; stenobiontic and hemistenobiontic groups are absent.

Among the dominant and codominant of the studied grassy plants of inundated meadows in relation to five soil factors, the dominating evribiontic group is also revealed, two species are hemievribionts, and other groups of tolerance are absent [4]. Therefore, the CPU considered prepotent and the codominant of types of inundated meadows can exist at considerable fluctuations of climatic and soil factors and are well adapted for conditions of the studied floodplains. It confirms that use of ecological scales for distribution of the CPU of types on fractions of valency will allow to allocate the limiting factors and to show an ecological variety of types.

At the same time processing of materials by model types of meadow polikarpic revealed that on the majority of factors the realized ranges are rather narrow, within $0.5-2.0$ points, and are similarin three considered parts of areas. At the detailed comparison it is established that the maximum ranges on all climatic factors and illumination are noted in a floodplain of Small Kokshaga at the CPU of seven types; on a thermoclimaticfactor - attheCPU of 13 types; onscales of continentality and ombroklimatic - at the CPU of 14 types to fractions. More considerable ranges are registered in a floodplain of Northern Dvina on a cryoclimatic scale and illumination-shading for a foxtail meadow, fescues meadow, a meadow grass and Veronicalongifolia. In afloodplain of the Oka River the maximum ranges are established for a red fescue on a cryoclimatic scale and for a clover on an illumination-shading scale.

To assess the degree of difference habitats CPU 15 species of meadow plants in the three areas of research carried out statistical analysis using two methods: analysis of variance Kruskal-Wallis test and the median test. It is established that on the vast majority of ecological factors score estimates of three habitats of the CPU of the studied types authentically differ ( $P \square 0.001$ ). Thus, in various parts of an area of the CPU of 15 model species of meadow plants prefer various combinations of ecological conditions. Further by means of a main component method, there were analyzed ranges of habitats of the CPU in three areas of research on 10 ecological scales for definition on what of ecological scales of D.N. Tsyganov [1] habitats of cenopopulation of the studied 15 meadow species of plants most differ.

It is revealed that the contribution of two main components in the general dispersion on ecological scales made 83\%. It is established that the greatest weight has the first main component $-72 \%$ of variability, and it positively correlated all soil scales and three climatic factors - Tm, $\mathrm{Kn}, \mathrm{Cr}$, and also with Lc scale. The second main component covers $11 \%$ of variability, and significant correlation on it isn't revealed. Therefore, all factors, except ombroklimatic, have significant impact on the CPU of the studied model types.

\section{Environmental Analysis of Protected Species of Plants}

Using ecological scales allows for more detail to carry out comparative studies in Floristry. As a rule, the analysis of flora is carried out according to the traditional scheme. Florists pay the main attention to the taxonomical and geographical analysis. Biomorphological, ecological, and ekologo-tsenotichesky features are characterized rather superficially. At best belonging it is considered to the largest groups of biomorph (trees, bushes, herbs). Determine vital forms by H. Raunkiyer even less often. Ecological and eco-cenotical ranges reflect proportions only of the most general groups in floristic works. Thus the role of concrete ecological factors in spatial distribution of the revealed fragment of a biodiversity remains not clear.

Ecological scales give the chance to receive very exact "ecological portraits" of each species. There is an opportunity on any ecological factor to characterize quantitatively the range in which the species can exist (its valency) and to estimate ecological tolerance in relation to separate factors and their complexes. Such specification allows to reveal "the internal ecological organization" of flora and its components. It is especially actual concerning protected species and invasive types. The understanding of a position of each species and their complexes in ecosystems of the region is necessary for increase of efficiency of the developed and realized programs. The analysis of ecological specialization of populations of types is possible.

We carried out the preliminary ecological analysis of the vascular plants included in Red Books of the Tver region [36] and the Mari El Republic (RME) [39] with use of scales by D.N. Tsyganov. Both regions are located within a forest zone of the East European Plain in the field of moderate and continental climate. Their southern borders have similar geographic latitude. However the degree of continentality of climate in RME is higher, and the region is near the border of a forest-steppe zone. The Tver region more than other areas of the Central Rossi is approached to Fennoscandia [40]. The area of the Tver region is 3.6 times more, and its territory is more varied in the physiographic and botanico-geographical relations.

Plants of Red Books in each of regions unite about 11-12\% of specific structure of flora. However total number of protected species and level of their taxonomical variety (162 views from 55 families against 107 views from 37 families) in the Tver region is 1.5 times higher [36,39]. These parameters reflect already noted specifics of regions in a certain degree. Distinctions of individual share of views with narrow ecological amplitude arent less significant.

In D. N. Tsyganor's scales there is information on 134 views from the Red Book of the Tver region [36] and 87 views from the Red Book of the Mari El Republic [39]. When comparing indexes climatic (It clim) and the general tolerance (It general), we established that in the Tver region, the views with low tolerance (stenobionta and hemistenobionta) is 1.82.2 times more, than in the Mari El Republic (Figure 2). The revealed distinctions are caused by botanico-geographical specifics of flora of the Tver region. Thanks to more considerable extent of the territory to the north and relative proximity to Fennoscandia in flora of the Tver region some geographical elements and vulnerable florotsenotchesky complexes, in a part of which there are a lot of stenobiont and hemistenobiont, are presented. Among them subatlantic (Lobelia dortmanna L., Subularia aquatica L.), Baltic (Gypsophila fastigiata L.), Central European and mountain (Lathyrus laevigatus (Waldst. \& Kit.) Gren., Ophrys insectifera L., Thesiumalpinum L.) types. Much better and more widespread in the Tver region is the group of stenobiontic and the hemistenobiontic of the hypoarctic types dated for large complexes of the sphagnum bogs, to key and minerotrophic swamps. Representatives of this group, specific in relation to RME, are Baeothryon alpinum (L.) T.V.Egorova, Betula humilis Schrank, Betula nana L., Carex heleonastes Ehrh. ex L.f., Petasites frigidus (L.) Fr., Primula farinosa L., Rhynchospora 
Citation: Dorogova YA, Zhukova LA, Turmuhametova NV, Polyanskaya TA, Notov AA, et al. (2016) Methods of Analysis of Environmental Diversity of Plants. Biol Med (Aligarh) 8: 354. doi: 10.4172/0974-8369.1000354.

Page 6 of 8

(a)

$\%$

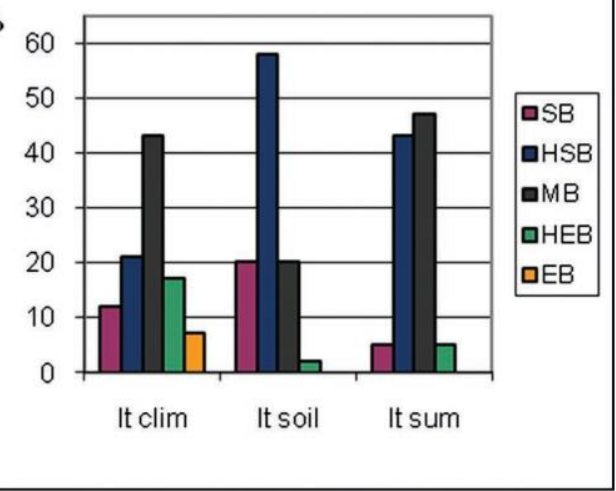

(b)

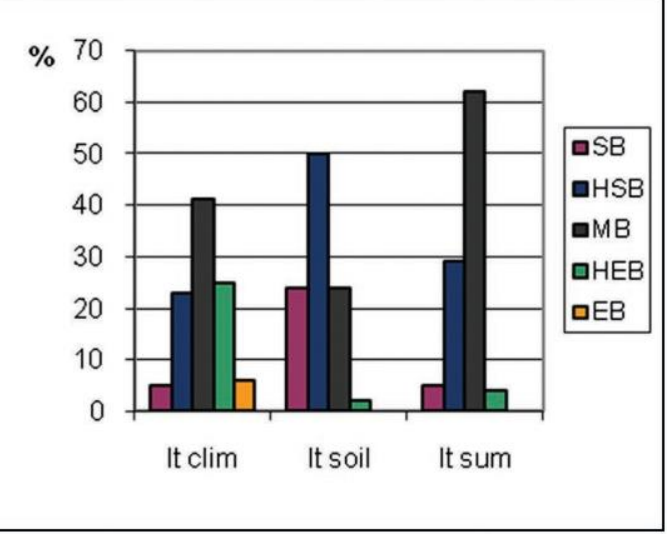

Figure 2: Distribution of the species included in the Red Book on groups of tolerance: A-Tver region; B-Mari El Republic; It climthe climatic index of tolerance, It soil-the soil tolerance index, It sum - the general tolerance, SB-stenobiont, HSB-

hemistenobiont, MB—mesobiont, HEB—hemievribiont, EBevribiont.

alba (L.) Vahl, etc. All types noted above on the general indicator of tolerance (It general) are stenobiont or hemistenobiont, and also show stenovalent ora hemistenovalent on the majority of factors.

Types, specific to RME, most often represent steppe, meadowsteppe, and nemoral groups. Among the types getting on a tolerance indicator (to It general) in group of stenobiont and hemistenobiont, only Astragalus falcatus Lam., Delphinium cuneatum Steven ex DC. are stenovalent or hemistenovalent on different factors. From 33 general for the Tver region and RME of types nearly a half (12) belong to Orchidaceae family [41]. Only 3 from them (Liparis loeselii (L.) Rich., Neottianthe cucullata (L.) Schltr., Orchis militaris L.) are hemistenobiont.

Distribution of groups of different valency in relation to ecological factors is presented in Figures 3 and 4. It testifies that a big role in restriction of ecological potentialities of protected species as in the Tver region, and RME play different soil characteristics - moistening of soils (Hd), variability of moistening of soils (fH), the salt mode (Tr). From of climatic factors more important for the two areas of our research is ombroklimatichesky factor (scale ecological aridity-humid climate, Om) (Figures 3 and 4).

The detailed ecological analysis of protected species in different regions - a perspective subject for future researches. Use of scales (a)

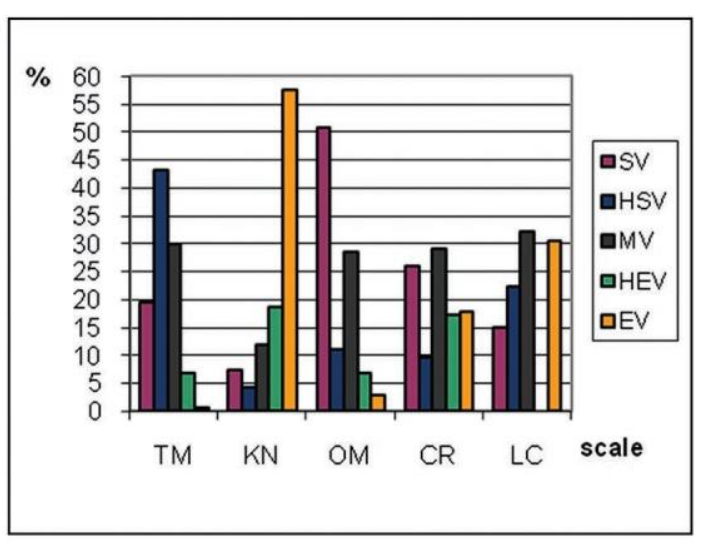

(b)

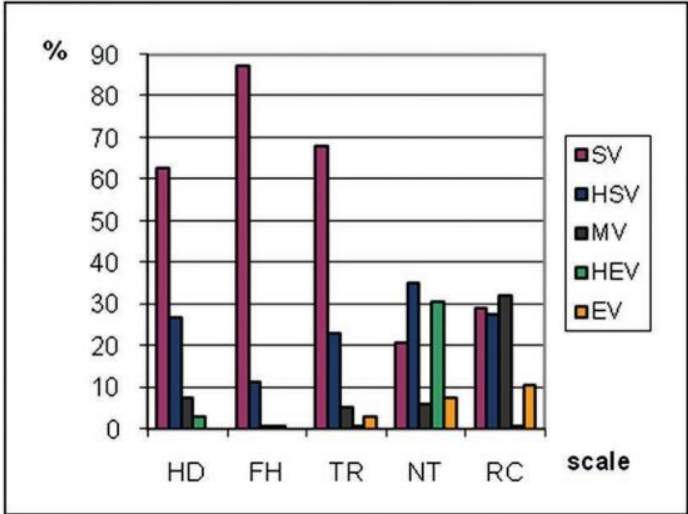

Figure 3: Ecological valency of the species included in the Red Book of the Tver region in relation to ecological factors: A-climatic factors: $\mathrm{Tm}$-thermoclimatic, $\mathrm{Kn}$-continentalities of climate, $\mathrm{Om}$ ombroklimatic of arid, humid climate, $\mathrm{Cr}$-crio-climatic; Lc-factor of light-shading; $\mathrm{B}$ - soil factors: $\mathrm{Hd}$-moistening of soils, $\mathrm{fH}$-variability of moistening of soils, $\mathrm{Tr}$ - the salt mode, $\mathrm{Nt}$ - the wealth of soils nitrogen, Rc-soil acidity; SV-stenovalent, HSV- hemistenovalent, MV-mesovalent, HEV-hemievrivalent, EV-evrivalent.

allows not only to detail the ecological characteristic of the protected plants but also to define the correlative importance of different factors in distribution of concrete species, their groups and complexes. Certainly, such information is extremely necessary for updating of lists of protected species, specification of their statuses, and development of recommendations about preservation of a regional biodiversity. However such researches willallow to understand biogegrafic specifics of the compared flora also more deeply.

\section{Conclusion}

The carried-out analysis of conditions of habitats of the central processing unit of model types of various vital forms showed that all of themborrow in differentparts of areas of the territory withrathernarrow ranges of the considered abiotic factors. It can serve as the real proof of fitness of the central processing unit of concrete types to cumulative influence of a certain set of climatic and soil factors of different regions. The probability of combinations of so narrow ecological positions on 10 ecological factors is small, and, therefore, the area of an area of any kind can be presented in the form difficult "a lacy pattern." In it larger congestions of individuals of the central processing unit of a concrete 
Citation: Dorogova YA, Zhukova LA, Turmuhametova NV, Polyanskaya TA, Notov AA, et al. (2016) Methods of Analysis of Environmental Diversity of Plants. Biol Med (Aligarh) 8: 354. doi: 10.4172/0974-8369.1000354.

Page 7 of 8

(a)

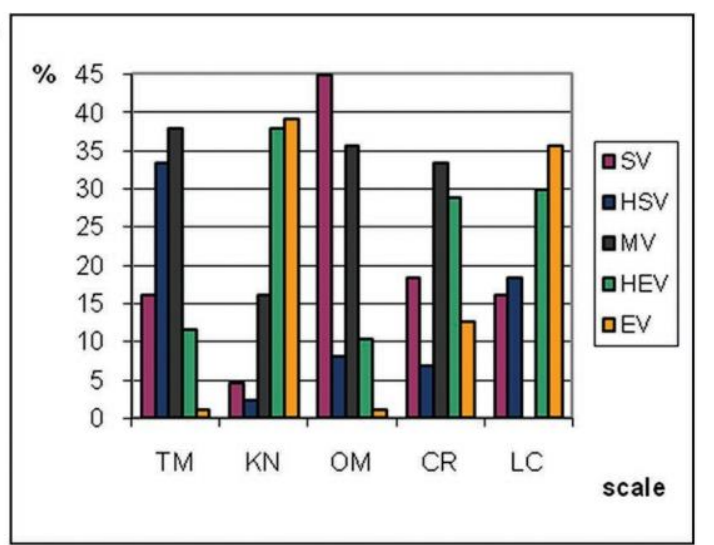

(b)

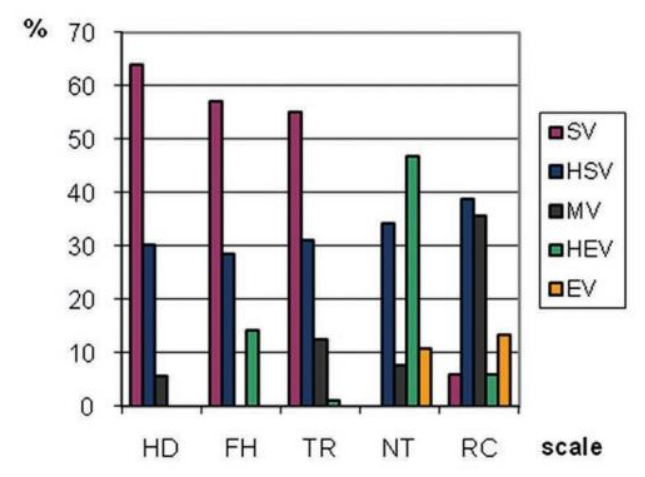

Figure 4: Ecological valency of the species included in the Red of the Mari El Republic in relation to ecological factors: A—climatic factors: Tm-thermoclimatic, $\mathrm{Kn}$-continentalities of climate, Om—ombroklimatic of arid, humid climate, $\mathrm{Cr}$-crio-climatic; Lcfactor of light-shading; B-soil factors: $\mathrm{Hd}$-moistening of soils, $\mathrm{fH}$ - variability of moistening of soils, $\mathrm{Tr}$ - the salt mode, $\mathrm{Nt}$ - the wealth of soils nitrogen, Rc-soil acidity; SV-stenovalent, HSV-hemistenovalent, MV-mesovalent, HEV-hemievrivalent, EVevrivalent.

species - "knots" - alternate with spaces where these congestions are absent. At the same time congestions in the central processing unit can connect among themselves thin strips or exist separately.

Substantially the spatial structure of an area and its separate sites, populated central processing units, is defined by a combination of various ranges of abiotic factors by different species. However it is necessary to call the description of this set of ranges of abiotic factors of a concrete species a fragment of its fundamental ecological niche, which can be presented in the form of the petal chart constructed with use of data about potential and the realized ecological valencies more precisely.

Use of a method of determination of potential ecological valency and characteristics of types on scales of factors gives the chance to solve a problem of a quantitative assessment of ecological tolerance of different types a biomorph and strategy in relation to separate factors or their complexes. These materials are necessary for the analysis of an ecological variety of communities, ecological preference of types in various vegetable zones, and also studying of ecological mechanisms of stability of populations of plants. The indicators of the potential and realized ecological valency and an index of tolerance offered by us can be applied to characteristics of ecosystems where the cenopopulation of these or those types, for an assessment of ecological positions of these types are presented rather widely. Their use is actual in comparative floristics and in the ecological analysis of the protected and invasive species of plants.

\section{References}

1. Tsyganov DN (1983) Phytoindication of the Ecological Modes in a Subband of the Coniferous and Broad-leaved Woods. Moscow: Science, p. 198.

2. Zhukova LA (2004) Assessment of Ecological Valency of Main Species Ecocenotic of Groups: East European Woods: History in the Holocene and the Present. Science, Moscow, pp. 256-270.

3. Zhukova LA, Turmuhametova NV, Akshentsev EV (2007) Ecological Characteristic of Some Species of Plants: Ontogenetic Atlas of Plants. JoshkarOla: Mari State University, pp. 318-331.

4. Dorogova YA, Zhukova LA, Turmukhametova NV et al. (2010) Ecological scales and methods of the analysis of an ecological variety of plants. JoshkarOla: Mari State University, p. 368.

5. Rabotnov TA (1995) History of Phytocenology. Moscow: Argus, p. 158.

6. Warming E (1884) Haandbogi den systematiskeBotanik. København.

7. Keller BA (1914) On Valleys and Mountains of Altai: Botaniko-geografichesky Researches. Kazan.

8. Cajander AK (1909) ÜberWaldtypen. Acta For Fennica 28:175

9. Gleason HA (1917) The Structure and Development of the Plant Association Bull Torrey Bot Club 44: 25.

10. Gleason HA (1939) The individualistic concept of the plant association. Am Midland Nat 21:31.

11. Ramensky LG (1915) To a question of the quantitative accounting of a grass cover. Mater Org Cult Fodder Areas 12: 105-140.

12. Ramensky LG, Tsatsenkin IA, Chizhikov ON, Antipov NA (1956) Ecological evaluation of the fodder lands by vegetation cover. Moscow: Selkhozgiz, p. 472.

13. Ellenberg H (1974) Ziegerwerte der Gefaspflanzen Mitteleuropeas. Scripta geobotanica 9: 197.

14. Ellenberg H, Weber HE, Dull R, Wirth V, Werner W, Paulisen D (1991) Zeigerwerte von Pflanzen in Mitteleuropa. Scripta Geobotanics 18: 248.

15. Landolt E (1977) Okologische Zeigerwerts zur Sweizer Flora. Veroff Geobot Inst ETH 64: 1-208.

16. Tsatsenkin IA (1967) Ecological Scales for Plants of Pastures and Haymakings of Mountainous and Flat Areas of Central Asia, Altai and the Urals. Dushanbe: Flame, p. 226

17. Tsatsenkin IA, Savchenko IV (1974) Methodical instructions by an ecologica assessment of fodder grounds of forest-steppe and steppe zones of Siberia on a vegetable cover. Moscow: Institute of forages, p. 246

18. Seledets VP (2000) A method of ecological scales in botanical researches in the Far East Russia. Vladivostok: Publishing house of the Far Eastern State University, p 248.

19. Komarova TA, Prokhorenko NB (2001) Regional ecological scales and their use at classification of the woods of the peninsula Ants Amursky. Bot Mag 86: 101-114.

20. Zaugolnova LB, Khanina LG, Komarov AS (1995) Informational and analytical system for an assessment of a suktsessionn condition of forest communities. Pushchino: Pushchino State University, p. 51.

21. Grokhlina TI, Khanina LG (2006) Automation of Processing of Geobotanica Descriptions on Ecological Scales. Principles and Ways of Preservation of a Biodiversity. Joshkar-Ola: Mari State University, pp. 87-89.

22. Zubkova EV, Khanina LG, Grokhlina TI, Dorogova YA (2008) Compute processing of geobotanical descriptions on ecological scales by means of the EcoScaleWin program. Joshkar-Ola: Mari State University, p. 96.

23. Scott T (1996) Concise Encyclopedia Biology. Berlin, Germany: Walter de Gruyter, p. 1287 
Citation: Dorogova YA, Zhukova LA, Turmuhametova NV, Polyanskaya TA, Notov AA, et al. (2016) Methods of Analysis of Environmental Diversity of Plants. Biol Med (Aligarh) 8: 354. doi: 10.4172/0974-8369.1000354.

Page 8 of 8

24. Kolasa J, Waltho N (1998) A Hierarchical View of Habitat and Its Relationship to Species Abundance: Ecological Scale: Theory and Applications. New York: Columbia University Press, pp. 55-76.

25. Ipatov VS (1964) About application of ecological tables for an assessment of species of the wood. Bull Leningrad State Univ, Biology Series 21: 150-152.

26. Grebenshchikov OC (1965) Geobotanical Dictionary. Moscow: Science, p. 226.

27. Stepanovskikh AS (2001) General ecology. Moscow: UNITY-DANA, p. 510.

28. Zhukova LA (2003) New aspects of the ecological analysis eco-cenotic of groups of forest and ecoton communities: VII Vavilovsky readings: globalization and problems of national security of Russia in the XXI century, Joshkar-Ola, pp. 152-154.

29. Dorogova YuA, Zhukova LA (2009) The ecological characteristic of cenopopulation of a linden heart-shaped in a subband of the coniferous and broad-leaved woods. Bull Kazan State Agric Univ 2: 155-160.

30. Zhukova LA, Polyanskaya TA (2010) Ecological variety of boreal forest and boreal edge eco-cenotic group of forest plants. Bull Kazan State Agric Univ 1(15): 140-145.

31. Smirnova OV (2004) East European woods: history in the Holocene and the present. Book 2. Moscow: Science, p. 575.

32. Dorogova YuA (2009) Apopulation and ecological variety of the most widespread species of wood plants in a subband of the coniferous and broadleaved woods. dis. ... cand. biol. sci.: 03.00.16 Joshkar-Ola, p. 246.
33. Zhukova LA (1995) Population Life of Meadow Plants. Joshkar-Ola: Lanar, p. 225.

34. Zhukova LA (2006) Polyalternativeness of development of organisms, populations and communities. Joshkar-Ola: Mari State University, p. 326.

35. Zaitsev GN (1984) Mathematical Statistics in Experimental Botany. Moscow: Science, p. 424.

36. Sorokin AS (2002) Red book of the Tver region. Tver: VecheTveri, ANTEK, p. 256.

37. Ogureeva GN (1999) Zones and types of zonation of vegetation of Russia and adjacent territories: the explanatory text and a legend to the card. Moscow: MSU, p. 64.

38. Ogureeva GN (2008) Levels and Scales of Identification of a Biodiversity of the Woods. Monitoring of Biological Diversity of the Woods of Russia. Moscow: Science, pp. 97-112.

39. (1997) Red Book of the Mari El Republic: The Rare and Needing Protection Plants of the Mari Flora. Joshkar-Ola: Mari Book Publishing House, p. 128.

40. Notov AA, Meysurova AF, Dementyeva SM (2013) Comprehensive biomonitoring of natural ecosystems of the central part of the Caspian-Baltic watershed. Fundam Res 10: 1090-1094.

41. Pushay ES, Dementyeva SM (2008) Biology, Ecology and Distribution of Species of Orchidaceae Juss. in the Tver Region. Tver: Tver State University, p. 206. 